\title{
Protective, curative and eradicative activities of fungicides against grapevine rust
}

\author{
Atividade protetora, curativa e erradicante de fungicidas no controle de ferrugem da videira
}

\author{
Francislene Angelotti ${ }^{\mathrm{I}}$ Claudia Regina Scapin Buffara ${ }^{\mathrm{II}}$ Dauri José Tessamnn ${ }^{\mathrm{II}}$ \\ Rafael Augusto Vieira II João Batista Vida ${ }^{\text {II }}$
}

\section{ABSTRACT}

The protective, eradicative and curative activities of the fungicides azoxystrobin, tebuconazole, pyraclostrobin+metiram, and ciproconazole against grapevine rust, were determined in greenhouse. To evaluate the protective activity, leaves of potted 'Niagara' (Vitis labrusca) vines were artificially inoculated with an urediniospore suspension of Phakopsora euvitis four, eight or forteen days after fungicidal spray; and to evaluate the curative and eradicative activities, leaves were sprayed with fungicides two, four or eight days after inoculation. Disease severity was assessed 14 days after each inoculation. All tested fungicides present excellent preventive activity against grapevine rust; however, tebuconazole and ciproconazole provide better curative activity than azoxystrobin and pyraclostrobin+metiram. It was observed also that all tested fungicides significantly reduced the germination of urediniospore produced on sprayed leaves.
\end{abstract}

- NOTE -
Key words: chemical control, Phakopsora euvitis, Vitis sp.

RESUMO

As atividades protetoras, curativas e erradicantes dos fungicidas azoxystrobin, pyraclostrobin+metiram, tebuconazole e ciproconazole foram avaliadas em relação à ferrugem, em casa de vegetação. Para a avaliação da atividade protetora, folhas de plantas de videira 'Niagara' (Vitis labrusca) foram artificialmente inoculadas com uma suspensão de urediniósporos de $\boldsymbol{P}$. euvitis aos quatro, oito e 14 dias após a pulverização dos fungicidas; e, para a avaliação das atividades curativas e erradicantes, as plantas foram pulverizadas com fungicidas aos quatro, oito e 14 dias após a inoculação do patógeno. A severidade da doença foi avaliada 14 dias após cada inoculação. Todos os fungicidas apresentaram excelente atividade protetora; no entanto, os fungicidas tebuconazole e ciproconazole proporcionam melhor controle curativo do que azoxystrobin e pyraclostrobin + metiram. Verificou-se também que todos os fungicidas testados reduziram significativamente a germinação dos urediniósporos produzidos nas folhas tratadas.

Palavras-chave: controle químico, Phakopsora euvitis, Vitis sp.
Grapevine rust, caused by the fungus Phakopsora euvitis Ono, has become a common late season foliar disease of grapevine (Vitis sp.) in some parts of Brazil (ANGELOTTI et al., 2008b). The symptoms initially appear as small yellow pustules containing uredinia, which may cover large portions of the abaxial leaf surface. Under severe rust infection, the disease can cause premature defoliation of vines, reduce plant growth and affect the development and ripening of grape berries (LEU, 1988).

The triazole fungicides tebuconazole and ciproconazole are used in Brazilian viticulture mainly to control powdery mildew and ripe rot, and strobilurin fungicides azoxystrobin and pyraclostrobin are used mainly to control downy mildew and to a lesser extent powdery mildew and ripe rot. However, only formulations with tebuconazole and pyraclostrobin + metiram (strobilurin+ditiocarbamate) are currently registered to control grapevine rust in Brazil. Thus, aiming to optimize the use of fungicides on grape production, the objective of this study was to evaluate the protective, curative and eradicative activities of fungicides against grapevine rust.

Potted 'Niagara Rosada' plants were obtained through propagation of cuttings in pots filled with $2000 \mathrm{~cm}^{3}$ of substrate. The top two buds above ground were treated with hydrogen cyanamide at $5 \%$, for uniform bud break. An isolate of $\boldsymbol{P}$. euvitis, obtained from a leaf collected in an orchard of 'Niagara Rosada' grapevine in Marialva, $\mathrm{PR}$, was maintained on leaves of potted transplants

\footnotetext{
IEmbrapa Semiárido, CP 23, 56302-970, Petrolina, PE, Brasil. E-mail: francislene.angelotti@embrapa.br. Autor para correspondência

${ }^{I I D e p a r t a m e n t o ~ d e ~ A g r o n o m i a, ~ U n i v e r s i d a d e ~ E s t a d u a l ~ d e ~ M a r i n g a ́ ~(U E M), ~ M a r i n g a ́, ~ P R, ~ B r a s i l . ~}$ Received 11.05.12 Approved 01.27.13 Returned by the author 06.03.14 CR-2013-1085.R1
} 
in controlled conditions. It was used 14-day old urediniospores produced on leaves of potted 'Niagara Rosada' plants, as inocula. For inoculation, a suspension of urediniospores $\left(1 \times 10^{5}\right.$ spores per $\left.\mathrm{mL}\right)$, amended with $0.01 \%$ of Tween 20 (Sigma Chemical Co., St. Louis, MO, USA), was sprayed to run-off onto abaxial surfaces of leaves using a hand-held spray bottle. The inoculated plants had shoots with 5-6 fully expanded leaves. After inoculation, plants were maintained in dew chamber for $12 \mathrm{~h}$, at 23 $25^{\circ} \mathrm{C}$, in darkness, and then transferred to a growth chamber at $23-25^{\circ} \mathrm{C}$ with 12 hours of photoperiod. To evaluate the protective activity of fungicides, potted plants were sprayed with fungicides at four, eight and 14 days before inoculation, using manual sprayer. The following treatments were compared: azoxystrobin $50 \mathrm{~g}$ a.i. ha $\mathrm{ha}^{-1}$, tebuconazole $100 \mathrm{~g}$ a.i. ha $^{-1}$, pyraclostrobin + metiram $50+550 \mathrm{~g}$ a.i. ha ${ }^{-1}$, ciproconazole $100 \mathrm{~g}$ a.i. $\mathrm{ha}^{-1}$, and "control" without fungicide. The concentration of each fungicide used in this experiment was based on the recommended for other diseases of the grapevine. The inoculation procedure and environmental conditions for disease development were the same as described above. To evaluate the curative and eradicative activities of fungicides, the plants were inoculated as previously described and treated with fungicides after two, four and eight days. The experimental design was completely randomized with four replicates, in a factorial arrangement with an additional control treatment. Individual plants were considered to be an experimental unit. The severity of the disease was assessed on all leaves of each plant for each treatment using a diagrammatic scale (ANGELOTTI et al., 2008a) on the $14^{\text {th }}$ day after the inoculation, and the percent disease control was calculated as $100 \times$ [the differences in severity values between treated and control plots]. To evaluate the eradicative effect of fungicides, the viability of urediniospores collected from leaves sprayed with fungicides was determined by the percentage of germinated spores in vitro. For this, urediniospores were collected 14 days after inoculation and a suspension was prepared using sterile water at the concentration of $10^{5}$ spores $\mathrm{mL}^{-1}$. An aliquot of $100 \mu \mathrm{L}$ of this suspension was spread evenly across surface in each Petri plate containing agar-water $2 \%$. The Petri plate were maintained at $25^{\circ} \mathrm{C}$ with a photoperiod of $12 \mathrm{~h}$. Germination percentages at $24 \mathrm{~h}$ incubation were determined by means of microscopic examination of 100 urediniospores at $\times 100$ magnification in each of the triplicate dishes. Individual urediniospores were considered germinated if the germ tube was equal to or greater than the minor diameter of the parent urediniospore. The experiment was repeated twice. Data were subjected to analysis of variance (ANOVA) using Sisvar computer programme (FERREIRA, 2000). The mean square of residues of factorial analysis was calculated and used for multiple comparisons. These procedures were accomplished using GENES software (CRUZ, 1998). The ScottKnott test at 5\% probability level was used to separate significant treatment means.

All tested fungicides presented protective and residual effects when sprayed until 14 days prior to inoculation, providing $100 \%$ control of grape rust. The first rust signs on leaves of control plants were observed at seven days after inoculation, which was about the same inoculation period reported by ANGELOTTI et al. (2008b). The average rust severity of the three inoculation timings was $47.5 \%$. The leaves that were sprayed with fungicides did not present rust signals. In the curative trial, significant effects were observed for fungicides, application timing and interaction between fungicide and application $(\mathrm{P}=0.05)$. The triazole fungicide tebuconazole and ciproconazole provided $100 \%$ control of grapevine rust when sprayed two and four days after inoculation. However, when sprayed eight days after inoculation provided 74.7 and $68.2 \%$ ( $1^{\text {st }}$ experiment) and 96.7 and $60.7 \%$ ( $2^{\text {nd }}$ experiment), respectively (Table 1$)$. The fungicide azoxystrobin and piraclostrobin + metiram were less efficient than the tebuconazole and ciproconazole in their curative activity against grapevine rust. In fact, these strobilurin fungicides presented more curative activity at two days after inoculation than at four or six days after inoculation.

Information about chemical control of grapevine rust is scarce in the scientific literature. Possibly, it is because the major viticultural areas of the world, which are actually in temperate regions, are free or do not have this disease as a major problem. Previous studies carried out in Brazil showed the efficiency of triazol and strobilurin on grape rust control in field (NARUZAWA et al., 2006); however, this study carried out in greenhouse approached the protective, curative and eradicative activities of these fungicides.

Significant factorial interaction was found between fungicides and application timing on $\boldsymbol{P}$. euvitis urediospores viability (Table 2). The germination of urediniospores produced on leaves treated with fungicides was significantly reduced compared to the control $(\mathrm{P}=0,05)$. Again, the most dramatic effects 
Table 1 - Curative effect of fungicides in grape rust control with sprayings at two, four and eight days after inoculation (DAY) with Phakopsora euvitis - $1^{\text {st }}$ experiment and $2^{\text {nd }}$ experiment.

\begin{tabular}{|c|c|c|c|c|c|c|c|}
\hline \multirow[t]{2}{*}{ Treatment } & & \multicolumn{2}{|c|}{------------ 2DAY ------------ } & \multicolumn{2}{|c|}{----------- 4DAY ------------ } & \multicolumn{2}{|c|}{----------- 8DAY ----------- } \\
\hline & & Severity $(\%)$ & Control (\%) & Severity $(\%)$ & Control (\%) & Severity $(\%)$ & Control (\%) \\
\hline Fungicide & $\mathrm{g}$ active ingredient $\mathrm{ha}^{-1}$ & ---------------- & ---------------- & ----- $1^{\text {st }}$ expe & imente ------- & ---------------- & --------------- \\
\hline Tebuconazole & 100 & $0.0 \mathrm{aA}^{(1)}$ & 100.0 & $0.0 \mathrm{aA}$ & 100.0 & $25.2 \mathrm{aB}$ & 74.7 \\
\hline Cyproconazole & 100 & $0.0 \mathrm{aA}$ & 100.0 & $0.11 \mathrm{aA}$ & 99.9 & $31.7 \mathrm{aB}$ & 68.2 \\
\hline Pyraclostrobin + Metiram & $50+550$ & $37.5 \mathrm{bA}$ & 77.2 & $58.3 \mathrm{bB}$ & 57.7 & $82.2 \mathrm{cC}$ & 17.7 \\
\hline Azoxystrobin & 50 & $39.7 \mathrm{bA}$ & 76.0 & $59.2 \mathrm{bB}$ & 57.2 & $81.5 \mathrm{bC}$ & 26.5 \\
\hline Control & & $60.4 \mathrm{c}$ & 0.0 & $72.1 \mathrm{c}$ & 0.0 & $89.9 \mathrm{~d}$ & 0.0 \\
\hline Tebuconazole & 100 & $0.0 \mathrm{aA}^{(1)}$ & 100.0 & $0.0 \mathrm{aA}$ & 100.0 & $2.1 \mathrm{aA}$ & 96.7 \\
\hline Cyproconazole & 100 & $0.0 \mathrm{aA}$ & 100.0 & $0.1 \mathrm{aA}$ & 99.7 & $25.4 \mathrm{bB}$ & 60.7 \\
\hline Pyraclostrobin + Metiram & $50+550$ & $21.8 \mathrm{bA}$ & 82.5 & $60.0 \mathrm{bB}$ & 39.7 & $55.0 \mathrm{~dB}$ & 15.0 \\
\hline Azoxystrobin & 50 & $13.7 \mathrm{aA}$ & 72.0 & $6.9 \mathrm{aA}$ & 89.0 & $49.3 \mathrm{cB}$ & 23.7 \\
\hline Control & & $67.5 \mathrm{c}$ & 0.0 & $63.2 b$ & 0.0 & $64.7 \mathrm{~d}$ & 0.0 \\
\hline
\end{tabular}

In a same experiment, the means followed by the same small letter in the column differ statistically by Scott-Knott test (5\% probability), and the means followed by the same capital letter in the line do not differ significantly by Scott-Knott test (5\% probability). Coefficient of variation: $1^{\text {st }}$ experiment $=3.96$ and $2^{\text {nd }}$ experiment $=14.03 \%$.

were caused by the triazole fungicides. All fungicides significantly reduced urediniospores viability even when sprayed eight days after inoculation. BUCK et al. (2011) and GACHOMO et al. (2009) found similar results using active principle of the same chemical groups when evaluating Puccinia triticina, P. hemerocallidis and Diplocarpon rosae spores germination, respectively.

The urediniospores germination phase, which occurs at pre-infection phase, is critical to pathogen establishment. Thus, the inhibition of the germination using fungicides is a fundamental practice to control the disease, since the urediniospores are the initial step for the propagation and survival of $\boldsymbol{P}$. euvitis. Thus, any control measures that reduce the viability of urediniospores are thought also to reduce survival of this rust. Chemical control used to reduce the initial inoculum can bring economic benefit by reducing the risk of epidemics (VALDEBENITOSANHUEZA et al., 2010).

All tested fungicides present excellent preventive activity against grapevine rust; however, tebuconazole and ciproconazole provide better curative activity than azoxystrobin and pyraclostrobin+metiram. It is expected that the information presented here can help growers to optimize the use of fungicides as well to plan effective fungicide programs to control grape diseases. Additionally, use of several groups of fungicides is important for the management of resistance of fungi to fungicides, being important to the rotation of products with different action mechanisms.

Table 2 - Percentage of germination (G) and reduce germination (RG) of urediospores of Phakopsora euvitis collected in "Niágara Rosada" grape plants treated with fungicides at two, four and eight days after inoculation.

\begin{tabular}{|c|c|c|c|c|c|c|c|}
\hline \multirow{2}{*}{$\begin{array}{l}\text { Treatment } \\
\text { Fungicide }\end{array}$} & \multirow[b]{2}{*}{$\mathrm{g}$ active ingredient $\mathrm{ha}^{-1}$} & \multicolumn{2}{|c|}{----- 2 DAY -----.- } & \multirow[b]{2}{*}{$\mathrm{G}(\%)$} & \multirow[b]{2}{*}{$\mathrm{G}(\%)$} & \multirow[b]{2}{*}{$\mathrm{G}(\%)$} & \multirow[b]{2}{*}{$\mathrm{G}(\%)$} \\
\hline & & $\mathrm{G}(\%)$ & RG (\%) & & & & \\
\hline Tebuconazole & 100 & -1 & & - & & $16.7 \mathrm{bB}^{2}$ & 72.8 \\
\hline Cyproconazole & 100 & - & & - & & 19.7 bB & 67.9 \\
\hline Pyraclostrobin + Metiram & $50+550$ & $2.2 \mathrm{aA}$ & 96,2 & $6.6 \mathrm{bA}$ & 89.7 & $24.0 \mathrm{bB}$ & 60.9 \\
\hline Azoxystrobin & 50 & $15.2 \mathrm{bA}$ & 74.0 & $13.1 \mathrm{bA}$ & 79.6 & $9.4 \mathrm{aA}$ & 84.7 \\
\hline Control & - & $58.5 \mathrm{cA}$ & - & $64.5 \mathrm{c}$ & - & $61.5 \mathrm{cA}$ & - \\
\hline
\end{tabular}

${ }^{1}$ Urediniospores not produced.

${ }^{2}$ Means followed by the same small letter in the column differ statistically by Scott-Knott test (5\% probability). Means followed by the same capital letter in the line do not differ significantly by Scott-Knott test (5\% probability). 


\section{ACKNOWLEDGEMENTS}

The authors would like to Coordenação de Aperfeiçoamento de Pessoal de Nível Superior (CAPES).

\section{REFERENCES}

ANGELOTTI, F. et al. Diagrammatic scale for assessment of grapevine rust. Tropical Plant Pathology, Brasília, v.33, p.439443, 2008a. Available from: <www.scielo.br/pdf/tpp/v33n6/ v33n6a06.pdf>. Accessed: abr. 27, 2012. doi: 10.1590/S198256762008000600006 .

ANGELOTTI, F. et al. Resistência de genótipos de videira à ferrugem. Pesquisa Agropecuária Brasileira, Brasília, v.43, p.1129-1134, 2008b. Available from: <http://webnotes.sct. embrapa.br/pdf/pab2008/09/43n09a05.pdf>. Accessed: mar. 24, 2012. doi: 10.1590/S0100-204X2008000900005.

BUCK, J.W. et al. Effect of postsymptom application of fungicides on urediniospore production by Puccinia triticina on wheat and P. hemerocallidis on daylily. Plant Disease, St. Paul, v.95, p.325-330, 2011. Available from: $<$ http://apsjournals.apsnet.org/ doi/pdf/10.1094/PDIS-09-10-0646>. Accessed: mar. 24, 2012. doi:10.1094/PDIS-09-10-0646.

CRUZ, C.D. Programa GENES - Aplicativo computacional em estatística aplicada à genética (GENES - Software for Experimental Statistics in Genetics). Genetics and Molecular Biology,
Ribeirão Preto, v.21, p.135-138, 1998. Available from: <http:// dx.doi.org/10.1590/S1415-47571998000100022>. Accessed: mar. 20, 2012. doi: 10.1590/S1415-47571998000100022.

FERREIRA, D.F. Sistema de análises de variância para dados balanceados. Lavras: UFLA, 2000. (SISVAR 4. 1).

GACHOMO, E.W. et al. Efficacy of triazoles and strobilurins in controlling black spot disease of roses caused by Diplocarpon rosae. Annals of Applied Biology, Warwick, v.154, 259-267, 2009. Available from: $<$ http://onlinelibrary.wiley.com/doi/10.1111/ j.1744-7348.2008.00297.x/pdf>. Accessed: mar. 24, 2012. doi: 10.1111/j.1744-7348.2008.00297.x.

LEU, L.S. Rust. In: PEARSON, R.C.; GOHEEN, A. C. Compendium of grape diseases. St. Paul: The American Phytopathological Society, 1988. p.28-30.

NARUZAWA, E.S. et al. Estudos epidemiológicos e controle químico de Phakopsora euvitis. Fitopatologia Brasileira, Brasília v.31, p.41-45, 2006. Available from: <http://dx.doi. org/10.1590/S0100-41582006000100007>. Accessed: mar. 30, 2012. doi: 10.1590/S0100-41582006000100007.

VALDEBENITO-SANHUEZA, R.M. et al. Controle do inóculo inicial para redução dos danos pela podridão: 'olho-de-boi' em macieiras. Revista Brasileira Fruticultura, Jaboticabal, v.32, 2010. Available from: <http://www.scielo.br/pdf/rbf/v32n4/aop14410.pdf>. Accessed: abr. 10, 2012. doi:10.1590/S0100-29452010005000127. 